Portland State University

PDXScholar

$12-1998$

\title{
Class Identity and the International Division of Labor: Sri Lanka's Migrant Housemaids
}

Michele Ruth Gamburd

Portland State University, b5mg@pdx.edu

Follow this and additional works at: https://pdxscholar.library.pdx.edu/anth_fac

Part of the Social and Cultural Anthropology Commons

Let us know how access to this document benefits you.

\section{Citation Details}

Gamburd, Michele Ruth, "Class Identity and the International Division of Labor: Sri Lanka's Migrant Housemaids" (1998). Anthropology Faculty Publications and Presentations. 44.

https://pdxscholar.library.pdx.edu/anth_fac/44

This Post-Print is brought to you for free and open access. It has been accepted for inclusion in Anthropology Faculty Publications and Presentations by an authorized administrator of PDXScholar. Please contact us if we can make this document more accessible: pdxscholar@pdx.edu. 
Class Identity and the International Division of Labor: Sri Lanka's Migrant Housemaids.

\author{
Michele Ruth Gamburd \\ Department of Anthropology \\ Portland State University \\ Portland, OR 97207-0751
}

13 December 1998 


\begin{abstract}
In 1996, 408,000 Sri Lankan women, nearly $10 \%$ of the country's working-age women, worked abroad, many of them in the oil producing countries of the Persian Gulf. In this paper I compare the influence of international migration on local hierarchies of class and gender in two villages in southern Sri Lanka: a Sinhala-speaking Buddhist village where I did my doctoral dissertation research in 1992-4, and a Tamil-speaking Muslim village where I spent some time during the summer of 1997. I discuss the challenges of using 'class' as a unit of analysis in a non-Western setting where gender identities, family ties, caste solidarity, religious allegiance, and ethnic affiliation also shape economic relations. Bringing female domestic servants into the global economy revolutionizes local understandings of both class and gender. Although it receives recognition as 'work', housework and childcare remain 'women's work', and women's internationally accepted gender status as unskilled, 'supplemental' family wage earners justifies meager salaries for housemaids. High Sri Lankan demand for scarce jobs in West Asia drives wages down and agency fees up, keeping housemaids 'working class' in the global economy. Isolated in the homes of their individual employers, migrant housemaids nevertheless are evolving a nascent class consciousness through their struggles with local Sri Lankan middlepeople and through retold stories of conflicts with abusive employers. Religious and ethnic differences between the Sinhala and Muslim villages affect the extent of class solidarity. The paper investigates how patterns social stratification, such as religious and ethnic practices, caste statuses, and gender roles affect the emergence of class identity in two villages in Sri Lanka.
\end{abstract}




\section{Introduction:}

Grossly unequal distributions of power, wealth, and prestige characterize the global economy. ${ }^{\text {i }}$ Poverty and lack of jobs for men and women in Sri Lanka drive women overseas to work as housemaids in the Middle East. This paper compares migration experiences of women in two villages, a Sinhala-speaking Buddhist village where I did my dissertation research in 1992-4, and a Tamil-speaking Muslim village where I spent some time during the summer of 1997. I argue that family patterns, household dynamics, and local, national and international economics influence women's work experiences. I also argue that patterns of social stratification, such as gender roles and religious and ethnic practices, affect class struggle and the emergence of class identity.

\section{Migration: poverty, unemployment, and the international division of labor}

Migration from Sri Lanka to the Middle East started in the mid-1970s when oil prices rose world-wide. At first the OPEC (Organization of Petroleum Exporting Countries) nations in the Middle East spent their profits building infrastructure, and many Sri Lankan men went abroad to work as carpenters, electricians, masons, and heavy-machinery drivers. When the building boom petered out in the early 1980s, the demand for male labor dropped, and families in the Middle East began to spend their disposable income to hire domestic servants. In 1996, 580,000 Sri Lankans worked abroad. Of these, 70\% were women, most of whom worked as housemaids in Saudi Arabia, Kuwait, and UAE (SLBFE 1997). These statistics suggest that nearly one in ten of the working-age women in Sri Lanka are now employed out of the country. While Muslims make up 6\% of the Sri Lankan population, Muslim women account for 20\% of 
the migrants. Muslim women’s over-representation in the migrant population show the importance of studying their experiences.

Comparing experiences of women from a Sinhala-speaking Buddhist village and a Tamilspeaking Muslim village allows me to ask how ethnicity, religious beliefs, and cultural practices influence migration and class consciousness. In 1994, the Sinhala village of Naeaegama (Village of Relatives) had 138 households with approximately 1000 inhabitants, divided into two main castes. ${ }^{\text {ii }}$ Over a quarter of the households had or had had a member working abroad, and 90\% of the migrants were women. The Muslim village of Minigoda (Many Gems) is about 25 miles south of Naeaegama, and in 1997 it had 500 households with roughly 3500 inhabitants. At least 200 people had experience abroad. Minigoda has no caste system of social stratification, but I noted a diversity of local rankings in status, wealth, and prestige. In both villages, population growth, poverty, and lack of jobs for either men or women make migration an attractive option. Most migrant women went abroad on two-year contracts with the goal of buying land, building a house, or supporting the daily consumption needs of their families (Brochmann 1987; Gamburd 1995).

Over the past twenty years, salaries have gradually dropped, while agency fees have increased. In international currencies, women earned about three times as much in 1980 as they did in 1994, when they earned about \$100 a month. Several international economic dynamics caused these changes. In 1985, when oil prices dropped, Arab employers lowered commissions paid to job agencies. At the same time, high demand for the limited number of jobs in the Middle East created competition between different labor exporting countries, and between agencies in Sri Lanka. With seemingly endless supplies of workers hoping to travel abroad, local and international agencies offered jobs to those willing to accept the lowest wages. In order to pay 
competitive commissions to Arab recruiters, agencies in Sri Lanka charged higher fees from prospective migrants. Agencies bargained away workers' rights, privileges, and salaries in order to secure scarce jobs. On the national front, remittances sent from the Middle East provided a major source of foreign exchange. Fearing that host countries will turn to Indonesia and the Philippines for cheaper labor, the Sri Lankan government has not actively supported workers’ rights. The combination of population growth, unemployment, national policies and international economic dynamics shapes men's and women's experiences of migration.

\section{Class struggle and class identity}

Marx discusses social structure in terms of relations of production, relations between people and people, and people and things (labor, machinery, and capital). Class emerges where the relations of production involve a differentiated division of labor. People with nothing to sell besides their labor find themselves at a disadvantage. Marx distinguishes between what laborers need to reproduce themselves and their families, and the exchange value of the labor they perform. Employers pay laborers less than the value of the work they do, which Marx refers to as the expropriation of surplus value. Such exploitation brings about class struggle.

In speaking about class, Marx distinguishes between 'class-in-itself' and 'class-for-itself'. 'Class-in-itself' refers to relatively objective economic relations of alienation and exploitation. Members of such a class, associated by their position in the division of labor, do not have a public or individual sense of group identity. Through class struggle, however, workers develop a sense of identity and grow into a self-conscious, politically active 'class-for-itself' (Marx 1978).

Using 'class' as a unit of analysis in Sri Lanka requires exploring what 'class' means in a non-Western setting. A purely Marxist analysis that sees economics as the base of all inequality 
neglects the multiple cross-cutting hierarchies of village life. For example, how does one classify the social place and identity of a woman who works abroad for extremely low wages (certainly working class in the global economy), of lower caste in the village, yet wealthy by local standards? Many individuals and families in both Naeaegama and Minigoda adopt a capitalist, individualist, 'Westernized' mindset, deriving status and prestige from wealth and education (Srinivas 1962). However, many of the same people also rely on traditional displays (such as giving to the temple or contributing to rituals) to mark their social standing. Individuals and families position themselves with respect to the multiple intersecting identities and oppressions of class, caste, race, and gender, searching to find, and to legitimate, the system offering them the most upward (or the least downward) mobility. Social mobility depends not only on progress and development within a given system, but also on the relative dominance of different competing systems in the village.

Refining and elaborating on Marx's insights, recent feminist anthropology examines how gender ideology, kinship, and household organization affect global economic processes and power structures (Comaroff 1985; Lamphere 1987; Ong 1987). Migration has brought about new ways of thinking about women's work and class identity. Scholars often fail to count femalegendered tasks as 'work', or to count unpaid housework as 'employment'. The myth of the housewife's economic inactivity supports cultural ideologies that devalue women's labor (Collier and Yanagisako 1987; Joan Scott 1988). The sale of domestic services on the global market forces both rural villagers and social scientists to recognize that the tasks housewives usually perform for free in fact make significant contributions to household finances (Sacks 1989).

In both Naeaegama and Minigoda, female migration changed images of men and women. As more and more married women went abroad, proper roles for mothers shifted to include long 
absences from home. Men, bereft of the 'breadwinner' role, suffered a challenge to their masculinity. In both villages, migrants reported hearing Arabs speculate that "Sri Lankan men must be donkeys because they send their women abroad to work.” Images of uneducated, slothful husbands suggested that men wasted the money their wives earned abroad. Sinhala stereotypes portrayed men turning to alcohol (an exclusively masculine beverage) to drown their troubles; in Muslim stereotypes, men did not drink, but smoked, gambled and womanized like their Sinhala counterparts. Representations of the delinquent, emasculated men appeared in tandem with the images of promiscuous, selfish, pleasure-seeking women who neglected their husbands and children.

Pragmatic migrants and their families countered the prevalent negative stereotypes. They described their families' poverty at home as an inevitable, irresistible, motivating force for their migration; citing their economic situation, they stressed their class identity as overshadowing any other idealized role. They argued that they remained morally and socially responsible individuals despite the migration experience. Supported by much-needed money from abroad, families creatively adapted new social configurations in response to women’s migration. Many families felt that the unmistakable benefits of migration outweighed the difficulties and problems associated with it. New, class-based attitudes and values emerged through slow, difficult, often painful negotiations of gender roles and family structures (Gamburd forthcoming).

Despite the growing recognition that housework is 'work', domestic service still does not rank as skilled or scarce labor. The common conception that women's work 'supplements' that of a male breadwinner often justifies low salaries, even in cases where women actually provide the bulk of a family's income. A steady supply of desperate women willingly take low-prestige, poorly paid jobs in order to provide something, no matter how little, for their families (Constable 
1997; Harrison 1997). Marx writes that "The proletarians have nothing to lose but their chains"(1971: 107). Analysis of gender and family ties suggests that men and women reach the level of having 'nothing to lose’ at significantly different points (Fernandez-Kelly 1983a, 1983b). For this reason, a discussion of gender must inform class analysis.

\section{Class struggle and ethnic identity}

Sri Lankan migrant women struggle against exploitation in two arenas: first, in their local communities, where middle-people such as job agents and moneylenders seek to siphon off profits from migration; and second in their overseas community, where their work is appropriated by their employers. I argue that Sinhala women feel more class solidarity than their Muslim counterparts because ethnic identity and religious practices influence their respective experiences and perceptions of oppression.

Migration patterns in the Sinhala village of Naeaegama had the potential to rearrange older economic hierarchies. At the same time, limited access to start-up capital perpetuated unequal class relations. Agencies charged four times more for a job for a man than they did for a job for a woman. Rich (often upper caste and upper class) families paid large sums to send men abroad to earn generous salaries; poor (often lower caste and lower class) families paid smaller sums to send women abroad to earn much more modest wages. Gender, caste and class thus influenced migration patterns.

Religious and ethnic identity also influenced migration strategies. Due to high demand for Muslim housemaids in the Gulf countries, Sri Lankan agencies charged lower fees for Muslim women than for Sinhala women. ${ }^{\mathrm{iii}}$ Muslim women tended to go abroad through registered agencies that provided a number of services to aid and shelter the migrant, while 
Sinhala women tended to go abroad through informal 'ticket' arrangements, and many did not purchase the supplemental government insurance that automatically accompanies agency jobs.

Muslims also had an advantage over their Sinhala countrywomen in terms of access to credit. Sinhala moneylenders provided ready cash without requiring collateral, thus giving even the poorest village women access to jobs abroad. But they charged 100\% interest on the loans women took to pay job agencies’ placement fees. Poor migrants found the services of moneylenders and job agents both crucially important and cripplingly expensive. The middlepeople creamed off the lion's share of the migrants' profits. In contrast, the Muslim community frowned on charging interest, and many Muslim women obtained loans for little or no charge. Percentage-wise more Muslim women than Sinhala women went overseas; they paid less for their jobs, they had more job security while abroad; and financially they profited more from their work than their Sinhala countrywomen. Ethnicity clearly affected which women went abroad, the price, security, and desirability of their jobs, and the amount of profit they could save for themselves and their families.

Although not always conceptualized locally in terms of class struggle, the adversity faced by Sinhala women in their dealings with job agents and moneylenders led them to evolve new strategies to protect their profits. Formal structures in the Sinhala village of Naeaegama positioned the middle-people to take large cuts out of many migrant women's finances. In 1997, I noted that more and more women went abroad by way of 'tickets' sent through informal female networks. By arranging employment for each other, women bypassed the job agents. By allowing the recipient of the job to pay the woman who organized it a reasonable 'finder's fee' after she started to earn a salary, the women bypassed the moneylenders. Such entrepreneurial schemes suggest a self-conscious working class solidarity that may successfully challenge older 
village patterns of wealth, power and poverty. In contrast, in the Muslim village, relatively inexpensive job opportunities and interest-free credit give fewer occasions for identity-forming struggles.

Class-for-itself refers to self-conscious working-class identity formed in the crucible of class struggle. Unlike unionized shop-floor workers, female domestic servants at work in the Middle East rarely have the opportunity to mingle, organize, and discuss their work situations. Instead, each works in the relative isolation of her employer's family, where issues of power, hierarchy, and workers' rights tend to seem like individual, interpersonal matters instead of topics for class solidarity and class action. I suggest that a group awareness based on a narrative genre of 'horror stories' represents a nascent class identity among Sinhala women. Muslim women told fewer stories of this sort, perhaps due to the religious tradition they shared with their employers. I argue that 'horror stories' paradoxically both quell worker rebellion and create a sense of solidarity among housemaids.

The genre of 'horror stories' emphasized the many dangers of working abroad and the severity of discipline meted out by Arab employers. My fieldwork did not take me to the Gulf States, so I can only speculate on relations between stories and real situations. By stressing the constructed nature of these stories, I wish in no way to deny the actual incidence of such violent events, or to minimize their importance. The images themselves, however, take on a life of their own, significantly at odds with the more mundane experiences of most housemaids I spoke with. Despite positive or even affectionate relations with their own employers, many women felt the need to relate second- and third-hand stories of violent encounters between housemaids and sponsors. 
Rumors of violence, fueled by the occasional first-hand experience, can intimidate large populations by creating what Michael Taussig calls a 'culture of terror' (1984). 'Horror stories' circulated an image of employers as strict disciplinarians who meted out sudden and terrible justice to erring maids. I asked a manpower recruiting agent if housemaids ever stole from their sponsors in Saudi Arabia; he said it never happened, because each housemaid knew that if she stole, her sponsors would cut off her hand. Migrant women in Naeaegama related similar stories of violent discipline. For example, one woman said that the family across the street from her in Kuwait beat their servant and kept her in a dark room without food for three days, because she had stolen some jewelry and hidden it in her jar of Nivea Cream. The narrator's employers brought her to see the errant housemaid, and told her to tell everyone that this was the punishment for stealing. The narrator analyzed the situation by saying that the Arabs showed everyone the punishments given to those caught in error, so that the rest could learn from the experience.

Stories about threats and punishments work to enforce discipline by spreading an image of the dominant group as masterful, omniscient, and omnipotent. In James Scott's terms, the powerful overdramatize their reputation in an effort to control the weak (1990:xi-xii). Scott questions the extent to which workers actually believe in such inflated reputations, suggesting 'hidden transcripts' that recognize the attempted deception. In this case, I wonder how selfconsciously housemaids challenge images of employer brutality. Whatever their beliefs and personal experiences, most Sinhala women related with passion at least one horror story during interviews. Perhaps retelling stories about 'the bad guys' in a common folk genre allows migrant women to create a community through fiction that they cannot easily find in fact. 
Horror stories exemplify hegemony, which is "the lived dominance and subordination of particular classes” (Williams 1977:110). While such stories can frighten workers into submission, they also create a strong group identity for migrant women. Meillassoux (1981) suggests that racism, xenophobia, and discrimination keep guest workers in foreign countries afraid and disorganized. Workers think of the issues and problems facing them as questions of ethnicity and nationality instead of questions of class. In contrast, I argue that the racist stereotype of the abusive Arab employer creates a community of 'survivors' among housemaids, providing them with a badge of courage that emphasizes the importance and difficulty of their undertaking, above and beyond the menial nature of their work. While domestic service isolates household workers and makes class consciousness difficult to achieve, horror stories bring women together in a common alliance against the image of the abusive employer. Paradoxically, in this case a racist stereotype serves both to discourage resistance and to enhance a consciousness and solidarity among housemaids that can function as a channel for nascent class awareness.

Religious affinity between Muslim women and their Muslim employers seemed to mitigate the extent of class solidarity experienced by Muslim migrants due to the circulation of horror stories. I asked both Minigoda and Naeaegama residents if they thought that sponsors abroad treated Sinhala and Muslim people differently. The Sinhalese felt that the Muslims were treated better abroad. Most Muslims claimed equal treatment for both ethnic groups, though several informants noted that many Arab people liked Muslim housemaids better than Christian or Buddhist ones. From this data, I speculate that Muslim women might receive some advantages in their interactions with their sponsors, but that both groups of women remained in a subordinate class position in the houses where they worked. 
Religious affinities figured into some Muslim discussions of migration. Though poverty motivated most Muslim migrants, one man asserted that his own wife went abroad because she wanted to make a pilgrimage to Saudi Arabia. This same religious tie offered some security to Muslim housemaids. Minigoda migrants who encountered trouble with their sponsors asked their families to send their employers a letter in Arabic from one of the four local mosques explaining the housemaid's grievance and requesting a solution. Access to religious support gave Muslims a degree of leverage unavailable to the average Sinhala maid. Though submerged in other relations of power and authority, the shared religious tradition did influence some of the ways Muslims thought about migration, and seemed to decrease their sense of class struggle against oppression.

\section{Conclusions}

This paper has compared the influence of international migration on local hierarchies of class and gender in two villages in southern Sri Lanka, the Sinhala-speaking Buddhist village of Naeaegama and a Tamil-speaking Muslim village of Minigoda. I discuss the challenges of using 'class' as a unit of analysis in a non-Western setting where gender identities, family ties, caste solidarity, religious allegiance, and ethnic affiliation shape economic relations. Bringing female domestic servants into the global economy revolutionizes local understandings of both class and gender. Although they receive recognition as 'work', housework and childcare remain 'women's work', and women's internationally accepted gender status as unskilled, 'supplemental' family wage earners justifies meager salaries for housemaids. High Sri Lankan demand for scarce jobs in West Asia drives wages down and agency fees up, keeping housemaids 'working class' in the global economy. Isolated in the homes of their individual employers, migrant housemaids nevertheless are evolving a nascent class consciousness through their struggles with local Sri 
Lankan middle-people and through retold stories of conflicts with abusive employers. Gender ideologies, religious beliefs, and ethnic identity enhance and inhibit the emergence of class consciousness in diverse and complex ways. 


\section{REFERENCES}

Brochmann, Grete 1987. Escape Route to Dependency? Female Migration from Sri Lanka to the Middle East. Oslo: International Peace Research Institute.

Collier, Jane and Sylvia Yanagisako 1987. Gender and Kinship: Essays Toward a Unified Analysis. Stanford, California: Stanford University Press.

Constable, Nicole 1997. Maid to Order in Hong Kong: Stories of Filipina Workers. Ithaca: Cornell University Press.

Fernandez-Kelly, Maria Patricia 1983a. “Mexican Border Industrialization, Female Labor Force Participation and Migration” in Nash and Fernandez-Kelly, eds., Women, Men and the International Division of Labor. Albany: SUNY Press.

Fernandez-Kelly, Maria Patricia 1983b. For We are Sold, I and my People: Women and Industry in Mexico's Frontier. Albany: SUNY Press.

Gamburd, Michele R. 1995. “Sri Lanka’s 'Army of Housemaids': Control of Remittances and Gender Transformations.” Anthropologica 37: 49-88.

Gamburd, Michele R. forthcoming. "Nurture for Sale: Sri Lankan Housemaids and the Work of Mothering," In Home and Hegemony, Sara Dickey and Kathleen Adams eds. University of Michigan Press.

Harrison, Faye V. 1997. “The Gendered Politics and Violence of Structural Adjustment” in Lamphere, Ragone and Zavella, eds., Situated Lives: Gender and Culture in Everyday Life. New York: Routledge. pp. 451-468.

Lamphere, Louise 1987. From Working Daughters to Working Mothers: Immigrant Women in a New England Industrial Community. Ithaca: Cornell University Press.

Marx, K. 1978. The Marx-Engels Reader. Second Edition. Ed. Tucker, Robert C. New York: W. W. Norton and Co.

Marx, Karl 1971. "Manifesto of the Communist Party” in Padover, ed., On Revolution. New York: McGraw-Hill Book Company. pp. 79-107.

Meillassoux, Claude 1981. Maidens, Meal and Money: Capitalism and the Domestic Economy. Cambridge: Cambridge University Press.

Ong, Aihwa 1987. Spirits of Resistance and Capitalist Discipline: Factory women in Malaysia. Albany: SUNY Press.

Sacks, Karen 1989. "Towards a Unified theory of class, race and gender" American Ethnologist 16 (3):534-549.

Scott, James C. 1990. Domination and the Arts of Resistance: Hidden Transcripts. New Haven: Yale University Press.

Scott, Joan 1988. Gender and the Politics of History. New York: Columbia.

Sri Lanka Bureau of Foreign Employment (SLBFE) 1997. Statistical Handbook on Foreign Employment. Colombo: Sri Lanka Bureau of Foreign Employment.

Srinivas, M. N. 1962. Caste in Modern India and Other Essays. Bombay: Asia Publishing House.

Taussig, M. 1984. "Culture of Terror-- Space of Death" CSSH 26.(3): 467-97.

Williams, Raymond 1977. Marxism and Literature. Oxford: Oxford University Press.

\footnotetext{
${ }^{\mathrm{i}}$ This research was made possible in part by NSF grant number DBS 9207143.
} 
${ }^{\text {ii }}$ My use of the terms 'Muslims' (a religious affiliation) for 'Tamil-speaking Muslims' and 'Sinhalese' (a linguistic affiliation) for 'Sinhala-speaking Buddhists' reflects widely used Sri Lankan terminology. I have replaced real names of people and villages with pseudonyms to preserve the privacy of the individuals involved in the research.

iii In 1997, US\$ 1 = 60/ Sri Lankan Rupees. Muslim women paid approximately Rs. 5000/ to 7500/ for an agency job with insurance. Sinhala women, faced with agency charges of Rs. 15,000/- to be paid in advance by borrowing Rs 30,000/ from a moneylender, often opted instead to pay a friend or acquaintance Rs. 12,000/ - Rs. 18,000/ for a ticket, and buy insurance for another Rs. 3,200/. Muslim women paid approximately Rs. 7000/- to 10,000/ (US\$ 117 to \$166) less than their Sinhala counterparts for jobs abroad. 